\title{
Novel Heteroleptic Ruthenium(II) Complexes with 2,2'- Bipyridines Containing a Series of Electron-Donor and Electron-Acceptor Substituents in 4,4'-Positions: Syntheses, Characterization, and Application as Sensitizers for ZnO Nanowire-Based Solar Cells
}

\author{
Fernando F. Salomón, Nadia C. Vega, Teodor Parella, Faustino Eduardo Morán Vieyra, \\ Claudio D. Borsarelli, Claudia Longo, Mauricio Cattaneo, and Néstor E. Katz*
}

Cite This: ACS Omega 2020, 5, 8097-8107

Read Online

ACCESS | Lill Metrics \& More | 国 Article Recommendations ｜ sl Supporting Information
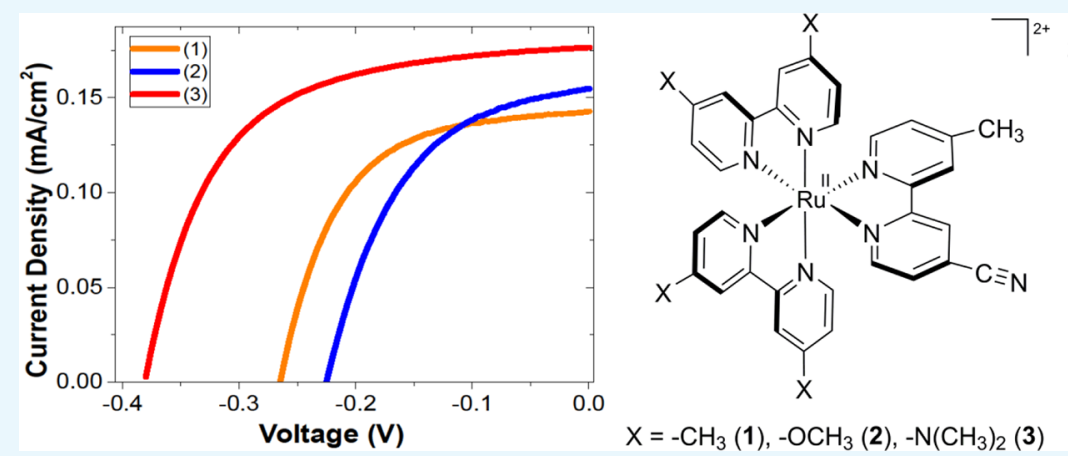

ABSTRACT: A novel series of complexes of the formula $\left[\mathrm{Ru}\left(4,4^{\prime}-\mathrm{X}_{2} \text {-bpy }\right)_{2}(\mathrm{Mebpy}-\mathrm{CN})\right]\left(\mathrm{PF}_{6}\right)_{2}\left(\mathrm{X}=-\mathrm{CH}_{3},-\mathrm{OCH}_{3},-\mathrm{N}\left(\mathrm{CH}_{3}\right)_{2}\right.$; Mebpy-CN = 4-methyl-2,2'-bipyridine-4'-carbonitrile) have been synthesized and characterized by spectroscopic, electrochemical, and photophysical techniques. Inclusion of the electron-withdrawing substituent $-\mathrm{CN}$ at one bpy ligand and different electrondonor groups $-\mathrm{X}$ at the 4,4'-positions of the other two bpy ligands produce a fine tuning of physicochemical properties. Redox potentials, electronic absorption maxima, and emission maxima correlate well with Hammett's $\sigma_{\mathrm{p}}$ parameters of X. Quantum mechanical calculations are consistent with experimental data. All the complexes can be anchored through the nitrile moiety of Mebpy-CN over $\mathrm{ZnO}$ nanowires in dye-sensitized solar cells that exhibit an improvement of light to electrical energy conversion efficiency as the electronic asymmetry increases in the series.

\section{INTRODUCTION}

Developing new materials for conversion of solar into electrical or chemical energy is a relevant area of research for the substitution of fossil fuels and mitigation of climate change. Dye-sensitized solar cells (DSCs) using n-type semiconductor materials such as $\mathrm{TiO}_{2}$ and sensitizers such as ruthenium complexes are promising low-cost devices based on the discovery of the Grätzel cell. ${ }^{1}$ Polypyridylruthenium(II) complexes have been extensively studied since their photophysical and redox properties are suitable for using them as sensitizers in optoelectronic devices and DSCs. ${ }^{2-4}$ The commercial dye $\mathrm{N} 719^{5}$ and the black dye ${ }^{6}$ are examples of efficient sensitizers that absorb a wide range of wavenumbers of visible light. Although they are very efficient converters, chemical stability problems arise when considering the possibility of decomposition of the -NCS group, as suggested before. $^{7}$

Tris-substituted bipyridineruthenium(II) complexes are highly stable and a large variety of chemical transformations in the bipyridine rings can be accomplished. It is well known that addition of electron-donor or electron-acceptor groups to the 4- and 4 '- positions of bpy (bpy $=2,2^{\prime}$-bipyridine) alter the physicochemical properties of trisbipyridineruthenium complexes. ${ }^{2}$ Bpys with electron-donor substituent groups have $\pi$ orbitals suitable to mix with $\mathrm{d}$ orbitals of $\mathrm{Ru}(\mathrm{II})$, the net effect being the destabilization of the highest occupied molecular orbital (HOMO). On the other hand, the lowest unoccupied molecular orbital (LUMO) is a $\pi^{*}$ orbital centered in the bpys and it can be stabilized by introducing electron-acceptor substituents in the bpy rings. The usual procedure to obtain red-emitting $\mathrm{Ru}(\mathrm{II})$ complexes is the addition of better $\pi$ -

Received: January 17, 2020

Accepted: March 24, 2020

Published: April 2, 2020 
acceptor ligands than bpy in order to decrease the energy of the LUMO and better $\sigma$-donor ligands than bpy in order to increase the energy of the HOMO, such as those complexes described by Hanan et al. ${ }^{8}$ The overall result of combining both trends is a decrease of the HOMO-LUMO gap and a shift of light absorption and emission maxima to the nearinfrared (NIR) spectrum region, among other physicochemical property changes.

With these modifications, the sensitization of a wide band gap semiconductor at longer wavelengths of the solar spectrum led to the creation of new electrodes in DSC devices, as already reported for $\mathrm{TiO}_{2}$-nanostructured electrodes. ${ }^{9,10}$ In recent years, $\mathrm{ZnO}$ have become very common in semiconductor devices ${ }^{11}$ due to its unique optical, chemical, electrical, and piezoelectrical properties, ${ }^{11-16}$ being also a material easy to obtain in different morphologies (films, nanoparticles, and nanowires $)^{17-19}$ and having the added possibility of making core-shell structures with other materials to change their optical and electrical properties. ${ }^{20,21}$ In the broad spectrum of challenges related to this issue, we address in this work the possibility of improving electron injection efficiency in ruthenium complex DSCs by a careful selection of coligands and using $\mathrm{ZnO}$ as a semiconductor, since its sensitization with $\mathrm{Ru}$ complexes has received much less attention. $\mathrm{ZnO}$ is currently considered as one of the most promising materials to replace the $\mathrm{TiO}_{2}$ semiconductor ${ }^{22}$ in solar energy conversion technology. In particular, $\mathrm{ZnO}$ nanowires (NWs) in a DSC create direct electron pathways, which lead to an increase of electron diffusion length and lifetime. ${ }^{22,23}$ In some of our previous studies, very efficient charge transfer between $\mathrm{Ru}$ complexes and $\mathrm{ZnO}$ nanowires ${ }^{24,25}$ was evidenced, indicating the possibility of exploring new $\mathrm{Ru}$ complex/ $\mathrm{ZnO}$ nanowire structures to develop better DSCs.

In this paper, three new ruthenium(II) polypyridyl complexes of the formula $\left[\mathrm{Ru}\left(4,4^{\prime}-\mathrm{X}_{2}-\mathrm{bpy}\right)_{2}(\mathrm{Mebpy}-\mathrm{CN})\right]$ $\left(\mathrm{PF}_{6}\right)_{2}$, where $\mathrm{X}=-\mathrm{CH}_{3},-\mathrm{OCH}_{3},-\mathrm{N}\left(\mathrm{CH}_{3}\right)_{2}$ and Mebpy$\mathrm{CN}=4$-methyl-2,2'-bipyridine-4'-carbonitrile, have been synthesized (Scheme 1). Electrochemical, spectroscopic, and

Scheme 1. Molecular Structures of the New Trisbipyridine Ruthenium(II) Complexes

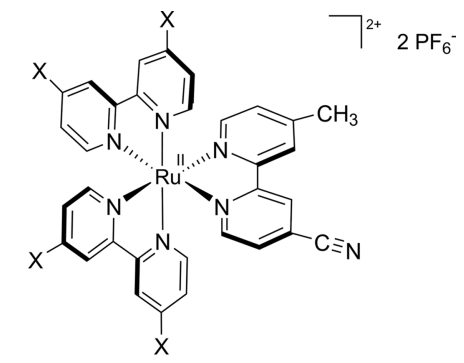

$\mathrm{X}=-\mathrm{CH}_{3}(\mathbf{1}),-\mathrm{OCH}_{3}(2),-\mathrm{N}\left(\mathrm{CH}_{3}\right)_{2}(3)$

photophysical studies have been carried out and the electronic properties can be rationalized by density functional theory (DFT) and time-dependent density functional theory (TDDFT) calculations. Finally, we demonstrate that $\mathrm{ZnO}$ nanowires, grown in fluoride tin oxide (FTO) substrates using a hydrothermal technique, can be sensitized by these complexes anchored to the semiconductor surface through a nitrile group and used as working electrodes in DSCs that perform at low efficiencies but could be improved by increasing the number of anchoring nitrile groups.

\section{RESULTS AND DISCUSSION}

Syntheses, IR, and NMR Spectra. The precursors $\mathrm{Ru}\left(4,4^{\prime}-\mathrm{X}_{2} \text {-bpy }\right)_{2} \mathrm{Cl}_{2}$ were prepared using procedures similar to those previously reported. ${ }^{26,27}$ As described by Pannwitz et al., ${ }^{27}\left[\mathrm{Ru}\left(4,4^{\prime}-\left\{\mathrm{N}\left(\mathrm{CH}_{3}\right)_{2}\right\}_{2} \text {-bpy }\right)_{2} \mathrm{Cl}_{2}\right] \mathrm{Cl}$ was obtained first as a $\mathrm{Ru}$ (III) precursor due to the stabilization of higher oxidation states induced by a strong electron-donor group in the bpy ring such as dimethylamine. For this particular complex, trimethylamine was added in the next preparative step in order to reduce $\mathrm{Ru}(\mathrm{III})$ to $\mathrm{Ru}(\mathrm{II})$. The new complexes 1-3 were prepared by protocols already known. ${ }^{26}$

Fourier transform infrared (FTIR) spectra of complexes 13 exhibit a very weak band at $2235 \mathrm{~cm}^{-1}$, which is characteristic of $\nu_{\mathrm{C} \equiv \mathrm{N}}$, the stretching vibration of the $\mathrm{C} \equiv \mathrm{N}$ group of Mebpy-CN. Typical bands corresponding to the vibrational modes of the polypyridyl moieties $\left(4,4^{\prime}-(\mathrm{X})_{2}\right.$-bpy and Mebpy-CN) are observed between 1600 and $1400 \mathrm{~cm}^{-1}$. Figure S2 shows the FTIR spectrum of complex 3 as a representative example. The values of $\nu_{\mathrm{C} \equiv \mathrm{N}}$ obtained using the Raman spectra of complexes 1-3 are identical with those measured by FTIR and almost equal to that of the free ligand, indicating that Mebpy-CN is not coordinated to the metal through the nitrile group.

Complexes $1-3$ possess $C_{1}$ symmetry and all the signals of the atoms of the substituted bpy ligands in the NMR spectra are therefore inequivalent. For this reason, signals of ${ }^{1} \mathrm{H}$ and ${ }^{13} \mathrm{C}$ for the $4,4^{\prime}-\mathrm{X}_{2}$-bpy ligands are reported as broad bands. On the other hand, signals for the Mebpy-CN ligand can be assigned straightforwardly by comparison with data previously reported for similar complexes with this ligand. ${ }^{25}$ Detailed assignments of ${ }^{1} \mathrm{H}-\mathrm{NMR},{ }^{13} \mathrm{C}-\mathrm{NMR}$, and ${ }^{15} \mathrm{~N}-\mathrm{NMR}$ signals of complexes $\mathbf{1 - 3}$ as well as mass spectroscopy (MS) data can be found in the Syntheses Section. Figures S3-S9 show all the NMR spectra of complex 3 as a representative example and the complete assignments are shown in Figure S10. NMR and MS results confirm the proposed structures depicted in Scheme 1.

Electrochemistry. Redox potentials of complexes 1-3 in $\mathrm{CH}_{3} \mathrm{CN}$ with $0.1 \mathrm{M}$ TBAH are shown in Table 1 . The first two

Table 1. Electrochemical Data for Complexes 1-3 in $\mathrm{CH}_{3} \mathrm{CN}$ vs $\mathrm{SCE}$

\begin{tabular}{lccccc}
$\quad$ complex & $E_{1 / 2}^{\mathrm{ox}}(\mathrm{V})$ & $E_{1 / 2}^{\mathrm{red} 1}(\mathrm{~V})$ & $E_{1 / 2}^{\mathrm{red} 2}(\mathrm{~V})$ & $E_{1 / 2}^{\mathrm{red}}(\mathrm{V})$ & $\Delta E_{1 / 2}(\mathrm{~V})^{a}$ \\
$\begin{array}{l}{\left[\mathrm{Ru}(\mathrm{bpy})_{2}(\mathrm{Mebpy}-\right.} \\
\mathrm{CN})]\left(\mathrm{PF}_{6}\right)_{2}\end{array}$ & 1.28 & -1.23 & -1.51 & -1.77 & 2.51 \\
$\mathbf{1}$ & & & & & \\
2 & 1.24 & -1.25 & -1.61 & -1.86 & 2.49 \\
3 & 1.06 & -1.26 & -1.61 & -1.76 & 2.32 \\
${ }^{a} \Delta E_{1 / 2}=E_{1 / 2}^{\mathrm{ox}}-E_{1 / 2}^{\mathrm{red} 1}$ & 0.64 & -1.38 & -1.62 & -1.93 & 2.03 \\
\hline
\end{tabular}

reduction potentials were measured by $\mathrm{CV}$, while the following ones were measured by DPV. The values for the reference complex of formula $\left[\mathrm{Ru}(\mathrm{bpy})_{2}(\mathrm{Mebpy}-\mathrm{CN})\right]\left(\mathrm{PF}_{6}\right)_{2}{ }^{25}$ were measured again under the same conditions. Cyclic and differential pulse voltammograms of complex 3 as a representative example are shown in Figures S11 and S12, respectively.

When the electron-donor strength of the substituent $\mathrm{X}$ of $4,4^{\prime}$ - $(\mathrm{X})_{2}$-bpy was increased, a cathodic shift of redox potential of the $\mathrm{Ru}^{\mathrm{II} / \mathrm{II}}$ couple, $E_{1 / 2}^{\mathrm{ox}}$, is observed. Less pronounced cathodic shifts are also observed for the redox potentials of the ligand reductions $E_{1 / 2}^{\mathrm{red} 1}, E_{1 / 2}^{\mathrm{red} 2}$, and $E_{1 / 2}^{\mathrm{red} 3}$. In polypyridylruthenium(II) complexes, when the metal center 
is oxidized to $\mathrm{Ru}(\mathrm{III})$, electron-donor groups in the bpy rings stabilize this latter state by sharing more electron density with the metal. The one-electron reduction process is expected to be centered in the best electron-accepting bpy, Mebpy-CN in this case. Increasing the electron-donor strength of the substituent $\mathrm{X}$ in the bpy rings changes the amount of metalto-ligand $\pi$-backbonding, making their reduction more difficult.

The one-electron oxidation process involves removal of an electron from the HOMO, which is a $d_{\pi}(\mathrm{Ru})$ orbital. On the other hand, the one-electron reduction process involves addition of an electron to the LUMO, which is centered in Mebpy-CN, as discussed in the Calculations Section. A plot of the difference of potentials of the oxidative and the first reductive processes, $\Delta E_{1 / 2}$, as a function of Hammett's sigma parameters $\sigma_{\mathrm{p}}{ }^{28}$ shown in Figure 1, is linear and evidences that

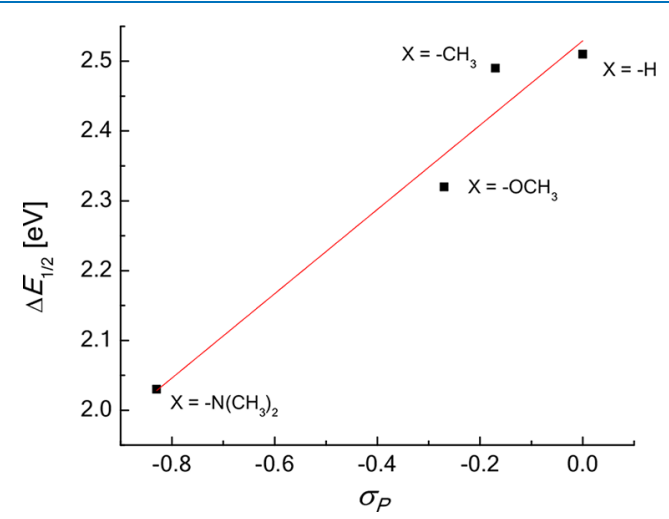

Figure 1. Difference of potentials, $\Delta E_{1 / 2}$,of the oxidative and the first reductive processes in $\left[\mathrm{Ru}\left(4,4^{\prime}-\mathrm{X}_{2} \text {-bpy }\right)_{2}(\mathrm{Mebpy}-\mathrm{CN})\right]\left(\mathrm{PF}_{6}\right)_{2}$ complexes as a function of Hammett's $\sigma_{\mathrm{p}}$ parameter of X.

increasing the donor strength of the substituent group $-\mathrm{X}$ destabilizes the HOMO more than the LUMO. This was already reported by Maestri et al. for a series of electron-donorsubstituted terpyridines. ${ }^{29}$ The net effect is a reduction of the HOMO-LUMO energy gap with the increase of the electrondonor strength of $-\mathrm{X}$, as discussed below.

UV-Vis Spectra. The electronic absorption spectra of complexes 1-3 are displayed in Figure 2. The absorption

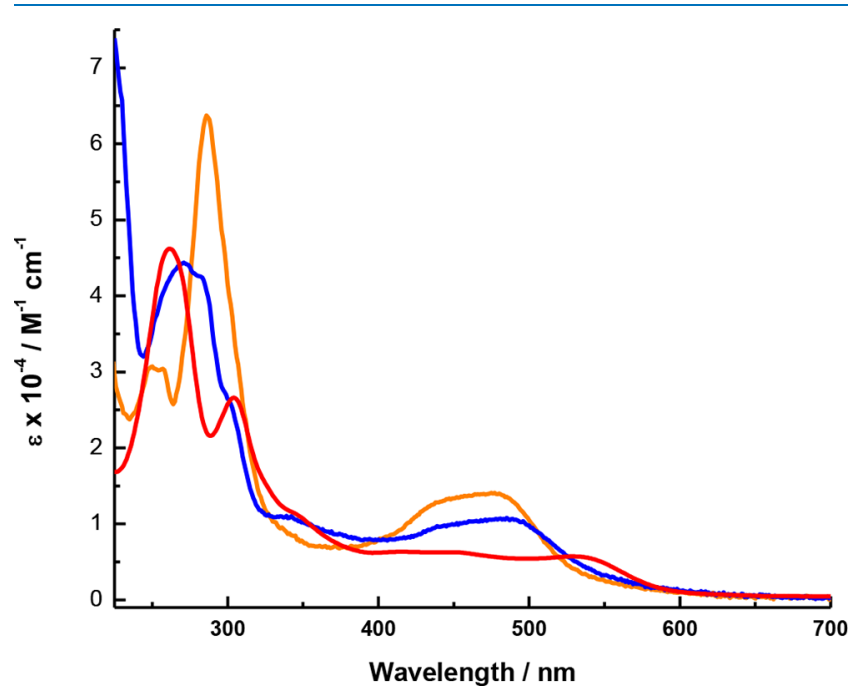

Figure 2. UV-vis spectra of complexes 1 (orange), 2 (blue), and 3 (red) in $\mathrm{CH}_{3} \mathrm{CN}$ at rt. maxima and molar extinction data are summarized in Table S1. For comparative purposes, data for $\left[\mathrm{Ru}(\mathrm{bpy})_{3}\right]\left(\mathrm{PF}_{6}\right)_{2}$ and $\left[\mathrm{Ru}(\mathrm{bpy})_{2}(\mathrm{Mebpy}-\mathrm{CN})\right]\left(\mathrm{PF}_{6}\right)_{2}$ have also been included in the table.

All the complexes show intense absorption bands in the visible region, which can be assigned to metal-to-ligand charge transfer (MLCT) transitions. ${ }^{2}$ As shown in Table S1, coordination of a $4,4^{\prime}-\mathrm{X}_{2}$-bpy ligand diminishes the wavenumber of the lowest-energy MLCT band in the order of increasing donor strength of $-\mathrm{X}$ :

$$
-\mathrm{H}<-\mathrm{CH}_{3}<-\mathrm{O}\left(\mathrm{CH}_{2}\right)_{2}<-\mathrm{N}\left(\mathrm{CH}_{3}\right)_{2}
$$

Besides, the asymmetry within the coordination sphere increases in the same order, resulting in splitting of all the visible absorption bands, as compared to $\left[\mathrm{Ru}(\mathrm{bpy})_{3}\right]\left(\mathrm{PF}_{6}\right)_{2}$ and $\left[\mathrm{Ru}(\mathrm{bpy})_{2}(\mathrm{Mebpy}-\mathrm{CN})\right]\left(\mathrm{PF}_{6}\right)_{2}$. The splitting goes from $0.20 \mathrm{eV}$ in complex $1\left(\lambda_{\max }=478\right.$ and $\left.444 \mathrm{~nm}\right)$ to $0.24 \mathrm{eV}$ in complex $2\left(\lambda_{\max }=488\right.$ and $\left.446 \mathrm{~nm}\right)$ and to $0.44 \mathrm{eV}$ in complex $3\left(\lambda_{\max }=532\right.$ and $\left.448 \mathrm{~nm}\right)$. As explained in the Calculations section, the least energetic band can be assigned to a $\mathrm{d}_{\pi}(\mathrm{Ru}) \rightarrow$ $\pi^{*}$ (Mebpy-CN) MLCT transition, while the following band can be assigned to a $\mathrm{d}_{\pi}(\mathrm{Ru}) \rightarrow \pi^{*}\left(4,4^{\prime}-\mathrm{X}_{2}\right.$-bpy $)$ MLCT transition. Absorption of visible light is thus extended to a broader range when increasing the donor strength of $-\mathrm{X}$, making complex 3-with $\mathrm{X}=-\mathrm{N}\left(\mathrm{CH}_{3}\right)_{2}$-almost black in color. The area below the two split bands is almost the same as that of the MLCT bands of $\left[\mathrm{Ru}(\mathrm{bpy})_{3}\right]\left(\mathrm{PF}_{6}\right)_{2}$. The maximum frequency of the lowest-lying MLCT band, $\nu_{\mathrm{MLCT}}$, and the electrochemical energy gap, $\Delta E_{1 / 2}$ (see Table 1$)$, are correlated linearly, as expected since both values depend on the HOMOLUMO gap. ${ }^{30}$

Spectroelectrochemistry. UV-vis-NIR spectroelectrochemical measurements for complexes 1-3 are shown in Figure 3. On one-electron oxidation, MLCT bands for all these complexes decrease in intensity, as expected upon changing the metal configuration from $\mathrm{d}^{6}$ to $\mathrm{d}^{5}$. Also, new bands arise at $\lambda_{\max }$ between 300 and $400 \mathrm{~nm}$, which can be assigned to intraligand charge transfer (ILCT) transitions in the oxidized species. Complex 3 exhibits a wide band at $\lambda_{\max }$ from 600 to $1000 \mathrm{~nm}$, which is not present in the other complexes. TD-DFT calculations of $3^{3+}$ show a set of ligand-to-metal charge transfer (LMCT) transitions from a $\pi\left(4,4^{\prime}\right.$-DMA-bpy) to a $\mathrm{d}_{\pi}-\mathrm{Ru}(\mathrm{III})$ orbital, as explained below in the Calculations Section. On the other hand, upon one-electron reduction, two new bands appear at $\lambda_{\max }$ around 350 to 370 and 530 to $550 \mathrm{~nm}$. Both are typical of bpy radical formation. ${ }^{31}$

Photophysical Properties. Table 2 shows the photophysical properties of complexes $1-3$ in $\mathrm{CH}_{3} \mathrm{CN}$ at room temperature, together with the previously studied complex with $\mathrm{X}=-\mathrm{H}^{25}$ The room-temperature emission spectra of complexes 1-3 are depicted in Figure S13.

Time-resolved differential absorption spectra of complexes 1-3, obtained by LFP, are shown in Figure 4. In all cases, bleaching of the MLCT bands and appearance of new bands at $\lambda_{\max }=370 \mathrm{~nm}$ are detected. This latter band is associated with ILCT transitions of the Mebpy- $\mathrm{CN}^{-}$radical and is unaffected by the electron-donor ability of $-\mathrm{X}$ in the substituted bpys. The spectroelectrochemical measurements described above show that upon one-electron oxidation and reduction of complexes 1-3, similar bands are detected; therefore, the lowest-lying MLCT excited state can be formulated as $\left[\mathrm{Ru}^{\mathrm{III}}\left(4,4^{\prime}-\mathrm{X}_{2} \text {-bpy }\right)_{2}(\mathrm{Mebpy}-\mathrm{CN})^{-}\right]^{2+}$. As the electron-donor ability of $\mathrm{X}$ increases, the excited state is stabilized and the 
(a)

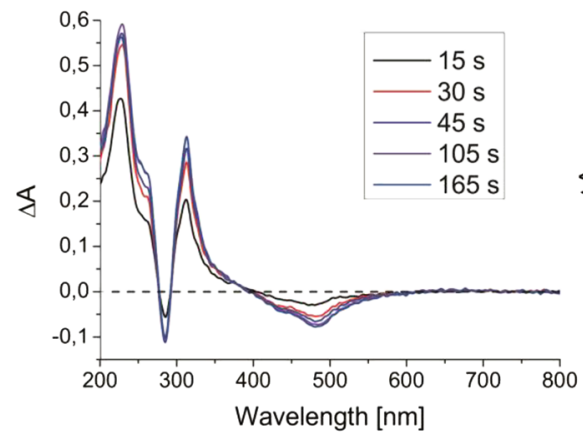

(1)

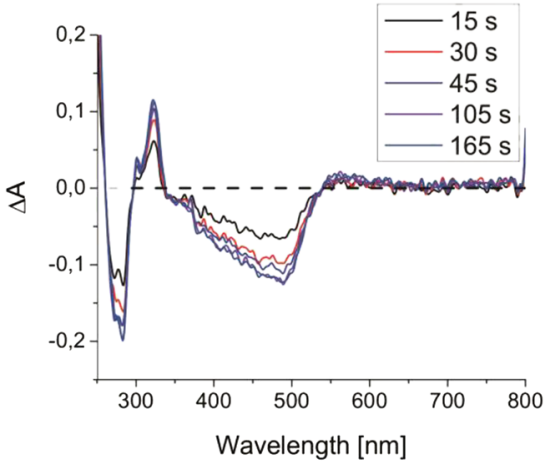

(2)

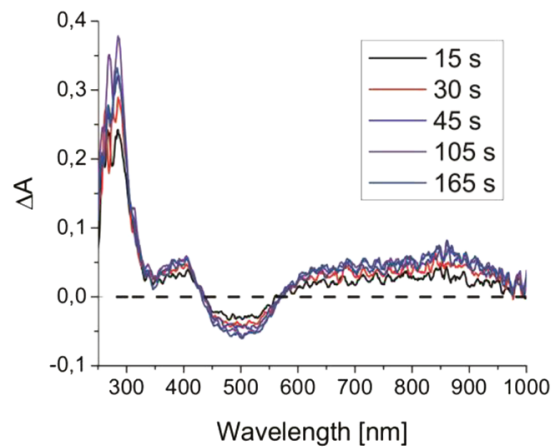

(3) (b)

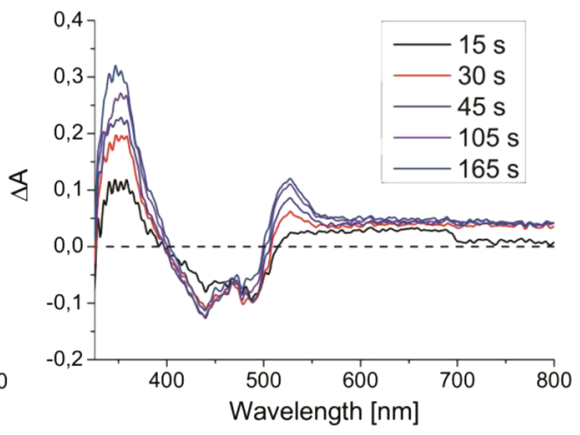

(1)

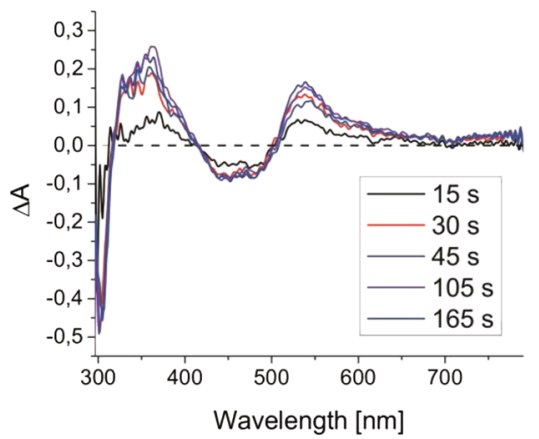

(2)

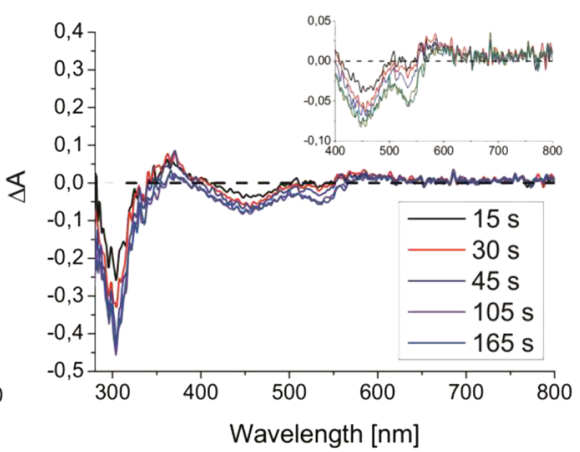

(3)

Figure 3. (a) Oxidative difference spectra acquired at an applied potential $100 \mathrm{mV}$ higher than the oxidative potential of the metallic center of complexes 1-3, respectively, in $\mathrm{CH}_{3} \mathrm{CN}$ solutions. (b) Reductive difference spectra acquired at an applied potential $100 \mathrm{mV}$ lower than the first reductive potential of complexes $1-3$, respectively, in $\mathrm{CH}_{3} \mathrm{CN}$ solutions.

Table 2. Photophysical Properties of Complexes 1-3 and $\left[\mathrm{Ru}(\mathrm{Bpy})_{2}(\mathrm{Mebpy}-\mathrm{CN})\right]\left(\mathrm{PF}_{6}\right)_{2}$ in $\mathrm{CH}_{3} \mathrm{CN}$ at $\mathrm{rt}$

\begin{tabular}{lcccccc}
\multicolumn{1}{c}{ complex } & $\lambda_{\mathrm{em}}[\mathrm{nm}]$ & \multicolumn{1}{c}{$\Phi_{\mathrm{em}}$} & $\tau[\mu \mathrm{s}]$ & $k_{\mathrm{obs}} \times 10^{-5}\left[\mathrm{~s}^{-1}\right]$ & $k_{\mathrm{r}} \times 10^{-5}\left[\mathrm{~s}^{-1}\right]$ & $k_{\mathrm{nr}} \times 10^{-5}\left[\mathrm{~s}^{-1}\right]$ \\
{$\left[\mathrm{Ru}(\mathrm{bpy})_{2}(\right.$ Mebpy-CN $\left.)\right]\left(\mathrm{PF}_{6}\right)_{2}$} & 623 & 0.120 & 0.76 & 13.2 & 1.58 & 11.6 \\
1 & 666 & 0.024 & 0.67 & 14.9 & 0.36 & 14.5 \\
2 & 709 & $9.3 \times 10^{-3}$ & 0.32 & 31.3 & 0.29 & 31.0 \\
3 & 798 & $2.0 \times 10^{-4}$ & 0.02 & 465 & 0.093 & 465
\end{tabular}

emission band shifts to longer wavelengths reaching the nearinfrared region (see Table 2 and Figure S13). The emission wavenumbers correlate with the MLCT absorption wavenumbers.

As predicted by the energy gap law, ${ }^{32}$ lowering of the energy gap between the excited and ground state is accompanied by an increase in the nonradiative kinetic constant, $k_{\mathrm{nr}}$, and consequently a decrease of the excited state lifetime.

Calculations. DFT and TD-DFT calculations allowed us to explain the experimental results that depend on electronic structures. Geometries were assumed to be the same as those of a similar complex determined by crystal structure studies. ${ }^{25}$ The molecular orbital energy levels of complexes 1-3 and 

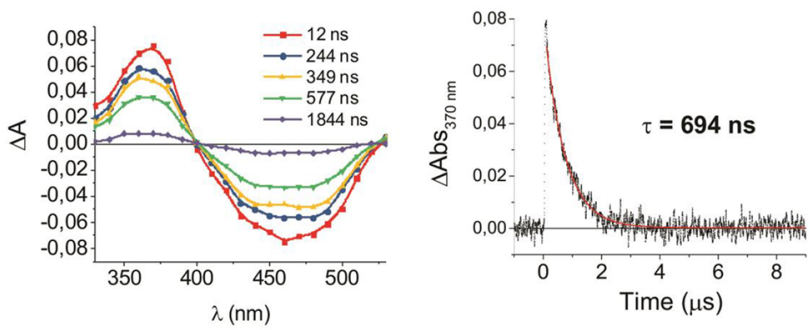

(1)
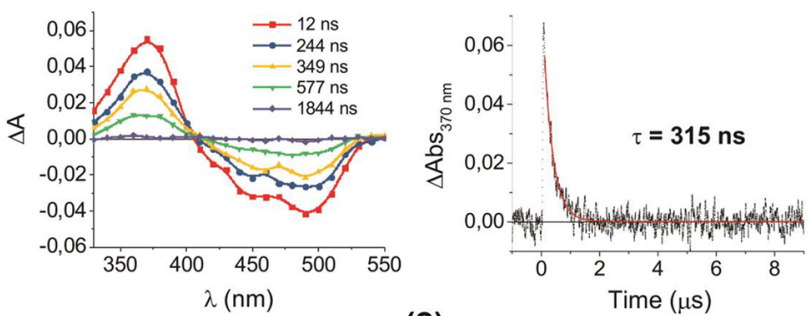

(2)
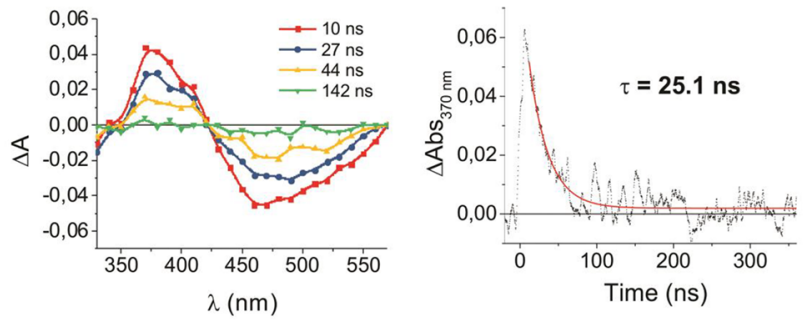

(3)

Figure 4. Time-resolved differential absorption spectra of 1 (top), 2 (middle), and 3 (bottom) in $\mathrm{CH}_{3} \mathrm{CN}$ solutions at different times $\left(\lambda_{\text {exc }}\right.$ $=370 \mathrm{~nm})($ left $)$ and the absorbance decay at $\lambda=370 \mathrm{~nm}$ and monoexponential fitting (right).

$\left[\mathrm{Ru}(\mathrm{bpy})_{2}(\right.$ Mebpy-CN) $]\left(\mathrm{PF}_{6}\right)_{2}$, calculated by DFT, are shown in Figure 5.

For all complexes (see Figure 5 and Table S2), the HOMOs are $\mathrm{d}_{\pi}-\mathrm{Ru}(\mathrm{II})$-type orbitals close in energy with some contribution of $\pi$ orbitals of $4,4^{\prime}-(\mathrm{X})_{2}$-bpy that increases with increasing electron-donor strength of $\mathrm{X}$. LUMOs for all

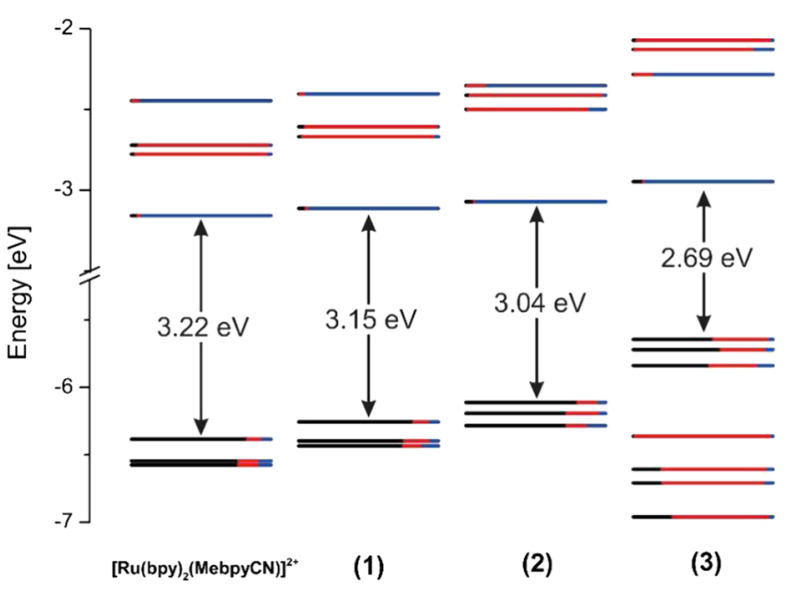

Figure 5. Molecular orbital (MO) diagrams calculated by DFT for complexes 1-3 and $\left[\mathrm{Ru}(\mathrm{bpy})_{2}(\mathrm{Mebpy}-\mathrm{CN})\right]\left(\mathrm{PF}_{6}\right)_{2}$. Different contributions of the groups are marked in different colors: ruthenium in black, $4,4^{\prime}-(\mathrm{X})_{2}$-bpy in red, and Mebpy-CN in blue. The HOMOLUMO energy gaps are also depicted. complexes are delocalized over the Mebpy-CN ligand. A small destabilization of the LUMO with an increase of the electron-donor strength of $\mathrm{X}$ is observed due to some mixing with $\pi\left(4,4^{\prime}-(\mathrm{X})_{2}\right.$-bpy $)$ orbitals. The overall effect of increasing the electron-donor strength of $\mathrm{X}$ is a decrease in the HOMOLUMO gap (see Figure 5). Orbital pictures of HOMOs and LUMOs for complexes 1-3 are displayed in Figure 6. For

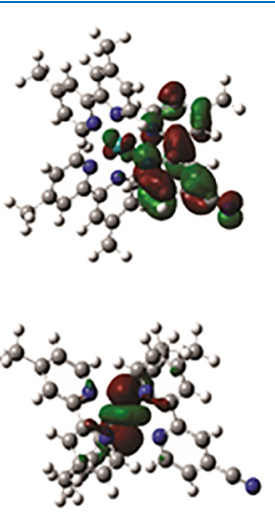

(1)
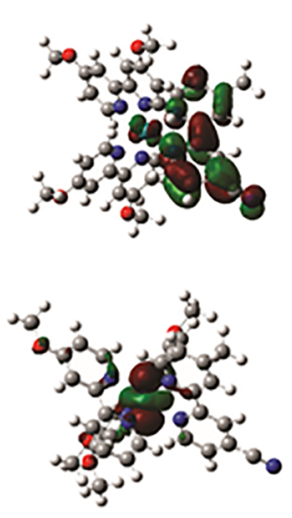

(2)

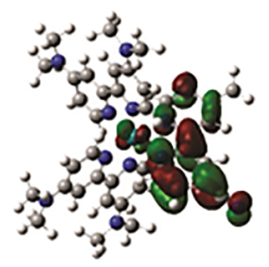

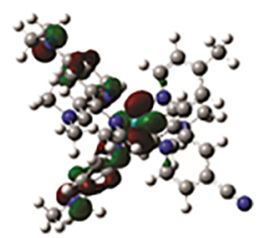

(3)
Figure 6. Orbital representations of LUMOs (top) and HOMOs (bottom) of complexes 1-3.

example, the HOMO of complex 3 has a larger contribution of orbitals localized at the bpy ligand with dimethylamino substituents, indicating higher delocalization between electron-donor-substituted bpys and metal orbitals than that observed for the other two complexes. This is also reflected in Table S2, where participation of $\mathrm{X}_{2}$ bpy in the HOMO increases from $10 \%$ in $\left[\mathrm{Ru}(\mathrm{bpy})_{2}(\mathrm{Mebpy}-\mathrm{CN})\right]^{2+}$ to $12 \%$ in $\mathbf{1}$, to $15 \%$ in 2 , and to $40 \%$ in 3 .

TD-DFT calculations of complexes 1-3 were done to support assignments of electronic transitions. Calculated transitions and experimental UV-vis spectra of complexes 1-3 are depicted in Figure 7. As stated before, a higher amount of splitting of both visible bands is observed when the electron-donor strength of $X$ grows. Since complex 3 has the larger asymmetry, it will be taken as the representative example to explain general features resulting from these calculations. The band at $\lambda_{\max }=532 \mathrm{~nm}$ in the spectrum of 3 is mainly assigned to HOMO-2 $\rightarrow$ LUMO, supporting the MLCT assignment of that band. The broad band at $\lambda_{\max }=448 \mathrm{~nm}$ in the experimental spectrum is assigned to a set of transitions from $\mathrm{d}_{\pi}-\mathrm{Ru}$ (II) orbitals (HOMO, HOMO-1, and HOMO-2) to $\pi^{*}$ ligand orbitals (LUMO, LUMO+1, LUMO+2, and LUMO+3) (see Table S3). As a considerable mixing of $\pi\left(4,4^{\prime}\right.$ $\left\{\mathrm{N}\left(\mathrm{CH}_{3}\right)_{2}\right\}_{2}$-bpy) and $\mathrm{d}_{\pi}-\mathrm{Ru}(\mathrm{II})$ orbitals is predicted (see above), these transitions can be assigned as MLCT/ LLCT. Moreover, the band at $\lambda_{\max }=304 \mathrm{~nm}$ in the experimental spectrum can be assigned to a transition from HOMO to a $4,4^{\prime}-\left(\mathrm{N}\left(\mathrm{CH}_{3}\right)_{2}\right.$-bpy-centered orbital (LUMO+8), being mostly MLCT in nature. Five strong transitions $(f>0.1)$ in the UV region $\left(\lambda_{\max } \approx 260 \mathrm{~nm}\right)$ confirm the ILCT $\pi \rightarrow \pi^{*}$ assignment of the band at $\lambda_{\max }=261 \mathrm{~nm}$ in the experimental spectrum. The calculated extinction molar coefficients are overestimated by a factor of 3 , as previously reported for similar complexes. ${ }^{25}$ Table S4 and Figure S14 show TD-DFT calculations for the oxidized species $3^{+}$that confirms the assignments discussed in the Spectroelectrochemistry Section. 

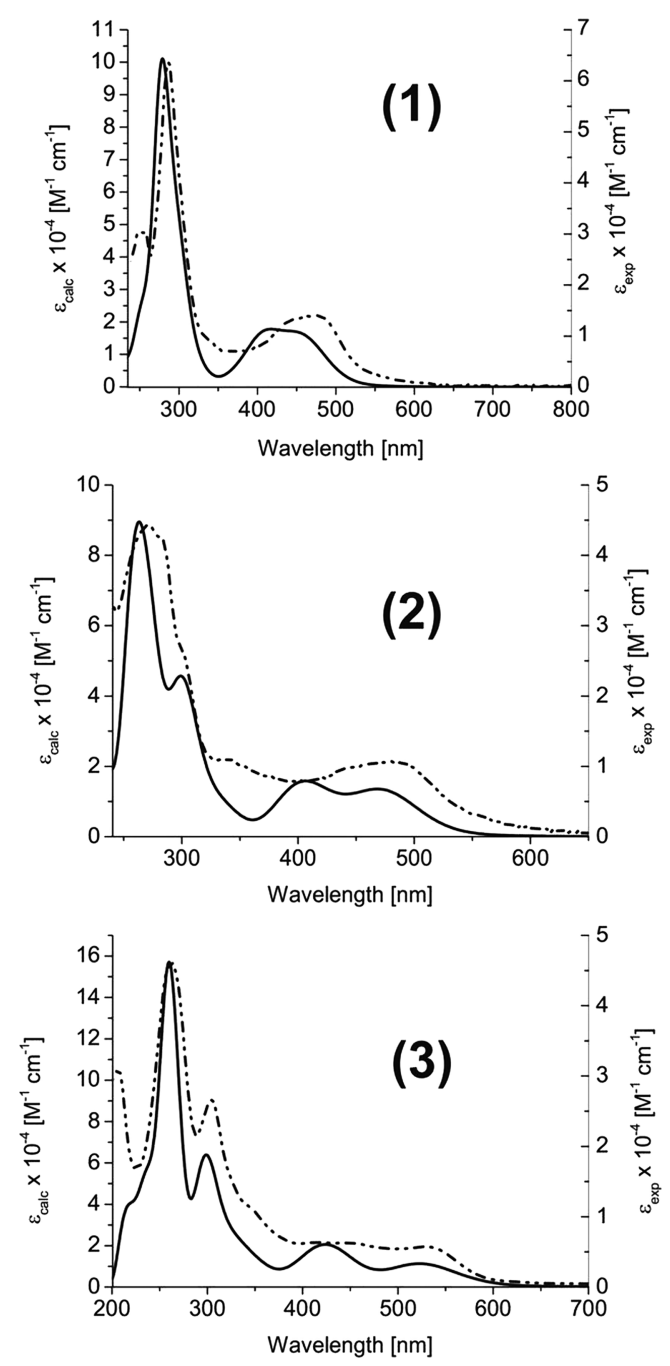

Figure 7. TD-DFT calculated (straight line) and experimental (dashed line) UV-vis spectra of complexes 1-3.

Application as Sensitizers for $\mathrm{ZnO}$ Nanowire-Based Solar Cells. Figure 8a,b shows the side and front SEM images, respectively, corresponding to a FTOIZnO NW sample grown by the hydrothermal technique; both images prove that nanowires are formed. Besides, the morphology of the $\mathrm{ZnO}$ NWs shows the expected hexagonal wurtzite structure in agreement with the XRD results, shown in Figure 8c, with a mean diameter of $100 \mathrm{~nm}$.

Electrodes of FTOIZnO NWs were characterized by EDAX, UV-vis, and Raman spectra. The EDAX spectrum, shown in Figure $\mathrm{S} 15$, indicates only the presence of $\mathrm{ZnO}$, evidencing the purity of this semiconductor. As shown in Figure 8c, the XRD patterns of $\mathrm{ZnO} N W s$, as compared with those of a standard $\mathrm{ZnO}$ polycrystalline powder sample, indicate that the NWs grew with a preferential orientation normal to the (002) plane, corresponding to the $c$ axis of the wurtzite structure. Secondary peaks, corresponding to (101) and (102) planes, are not present in the NW structure. The normalized UV-vis spectra of $\mathrm{ZnO}$ NWs sensitized with complexes 1-3 are displayed in Figure S16; they present bands in the visible region, which correspond to those previously measured in $\mathrm{CH}_{3} \mathrm{CN}$ solutions of complexes 1-3, as shown in Figure 2, which are somewhat masked by bands in the UV region due to the $\mathrm{ZnO}$ NWs.
Raman spectra of FTOIZnO NW electrodes sensitized by complexes 1-3 are shown in Figure S17. In all cases, two bands are detected in the nitrile stretching frequency region, $\nu_{\mathrm{C} \equiv \mathrm{N}}$ : one at $2240 \mathrm{~cm}^{-1}$, which is identical with those measured in the FTIR spectra of the solid complexes, as described before, corresponding to free nitriles, and one at $2333 \mathrm{~cm}^{-1}$, which can be assigned to nitrile groups bound to the $\mathrm{ZnO}$ surface, indicating chemical adsorption of the complex on the semiconductor. This shift has been observed before when the complex with $\mathrm{X}=\mathrm{H}$ was adhered to $\mathrm{TiO}_{2} \cdot{ }^{33}$ The appearance of an unbound dye can be attributed to the presence of only one anchoring nitrile group in all the complexes studied here. Ongoing work on the series $\left[\mathrm{Ru}\left(4,4^{\prime}\right.\right.$ $\mathrm{X}_{2}$-bpy) $\left.(\text { Mebpy-CN })_{2}\right]\left(\mathrm{PF}_{6}\right)_{2}$ containing two anchoring nitrile groups will hopefully improve the quantity of sensitizers adsorbed on the surface and consequently the solar cell efficiency. It must be noted that the highest efficiency was detected in our previously studied $\mathrm{Ru}$ systems with two nitrile groups adsorbed on $\mathrm{TiO}_{2}{ }^{33}$

The QE spectra of the solar cells, Figure 9a, were acquired under ambient temperature $\left(25 \pm 1{ }^{\circ} \mathrm{C}\right)$. The higher efficiencies were observed for incident radiation with the wavelength ranging from 450 to $600 \mathrm{~nm}$, consistent with the UV-visible spectra of sensitized FTO $\mathrm{InO} \mathrm{NW}$ electrodes (Figure S16). A red shift in the QE band of the electrode is detected when going from 1 to 3 , showing that the sample sensitized with complex 3 presents a higher value of efficiency than the other complexes for identical times of immersion and a better response to lower wavelengths. In Figure $9 \mathrm{~b}, I-V$ curves for all the solar cells are presented: they were obtained under irradiation with a solar simulator (linear sweep voltammetry, $5 \mathrm{mV} \mathrm{s}^{-1}$ ) at $28 \pm 1{ }^{\circ} \mathrm{C}$. Table 3 shows the parameters obtained for these DSCs: under polychromatic irradiation, they all show an overall efficiency, $\eta$, of $0.03-0.017$ $\%$, open circuit voltages $\left(V_{o c}\right)$ in a $0.38-0.26 \mathrm{~V}$ range and short circuit current values between 0.17 and $0.14 \mathrm{~mA} / \mathrm{cm}^{2}$. Considering these data, the best photoresponse was that of the cell sensitized by complex 3, according to its higher absorption in the NIR region. When comparing these data with the reference N719, the efficiencies were found to be lower by a factor of 10 for our complexes in the same conditions, as expected because of lower adsorption of the dyes, as discussed before. Although the efficiencies obtained are low, our data support the fact that panchromatic shifts in absorption lead to increasing photocurrent generation by modulating the electronic asymmetry by small structural changes in the sensitizer. We hope to improve the cell performances using complexes with two anchoring nitrile groups.

It has already been reported that very low efficiencies are obtained when loading ruthenium polypyridyl complexes onto $\mathrm{ZnO}$ surfaces with anchoring carboxylate groups. ${ }^{34} \mathrm{We}$ demonstrate in this work that anchoring similar complexes with nitrile groups onto $\mathrm{ZnO}$ nanowires is a promising approach when combined with the occurrence of panchromatic shifting induced by small structural variations in the bipyridine rings as described in this work.

\section{CONCLUSIONS}

Changing the electron-donor ability of substituent $-\mathrm{X}$ in heteroleptic complexes of the formula $\left[\mathrm{Ru}\left(4,4^{\prime}-(\mathrm{X})_{2}\right.\right.$ bpy $)_{2}($ Mebpy-CN $\left.)\right]^{2+}$, with $\mathrm{X}=-\mathrm{CH}_{3},-\mathrm{OCH}_{3}$, and $-\mathrm{N}$ $\left(\mathrm{CH}_{3}\right)_{2}$, allows us to obtain a fine tuning of the electronic properties of this series of new complexes. Enhancing 

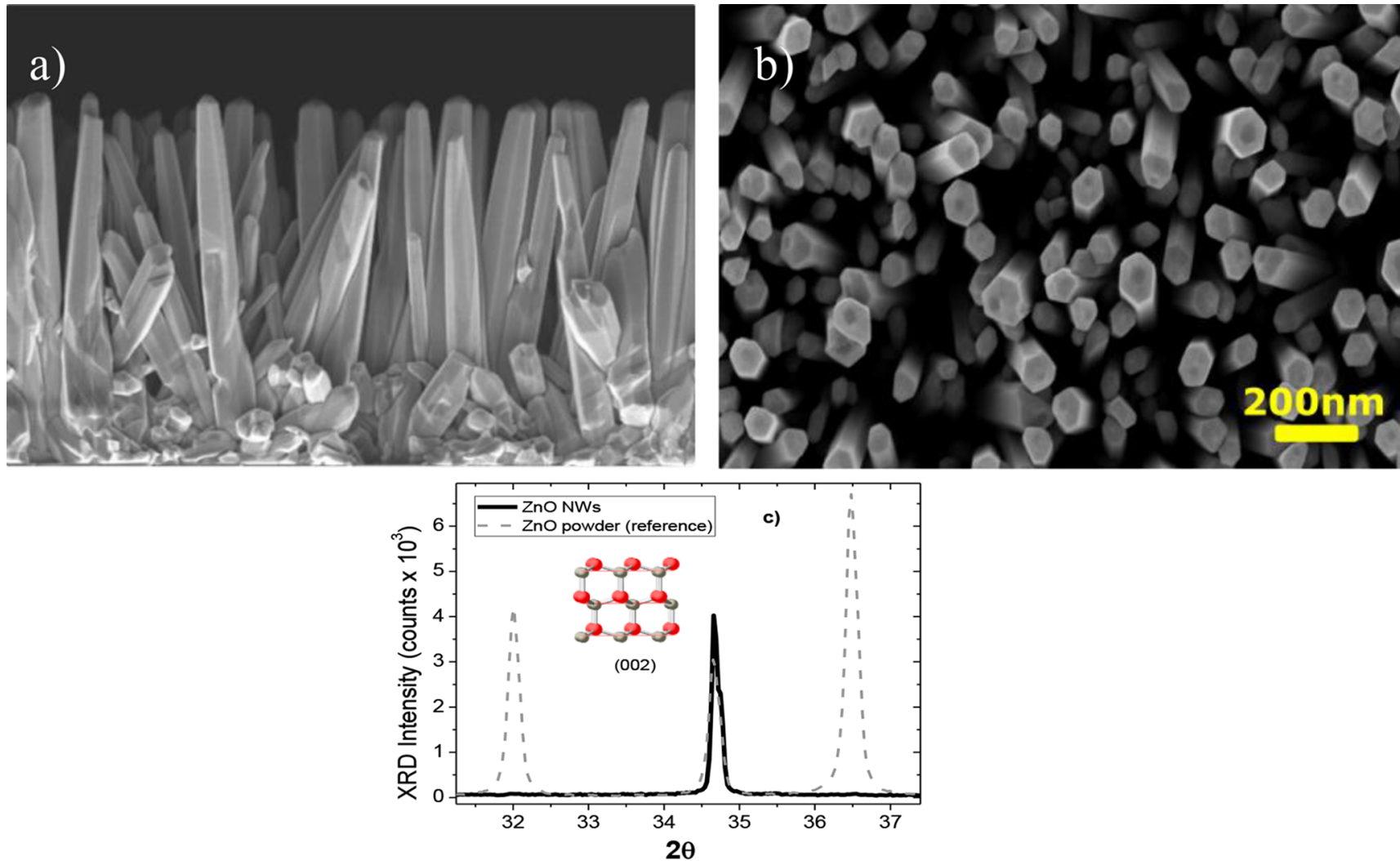

Figure 8. (a) Side and (b) front view SEM images of ZnO NWs grown using the hydrothermal technique. (c) XRD data of FTOIZnO NWs compared with those of a bulk sample of the $\mathrm{ZnO}$ (commercial powder) spectrum.

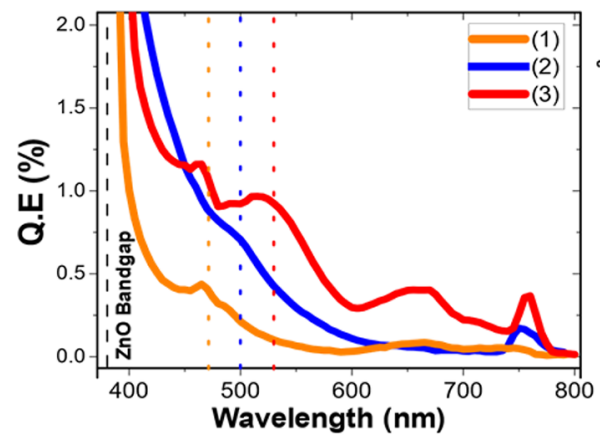

(a)

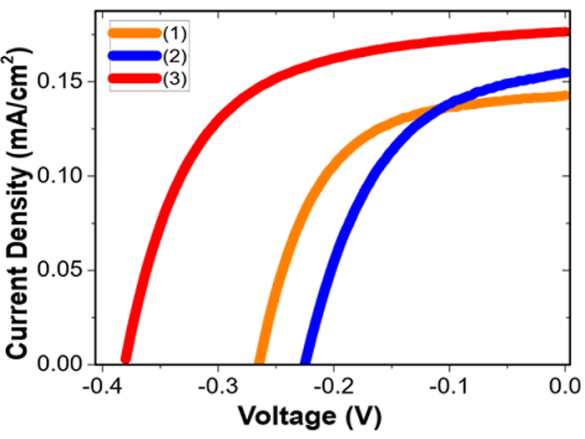

(b)

Figure 9. Performance of solar cells assembled with the sensitized FTOIZnO NWs, Pt counter electrodes, and a liquid electrolyte: (a) quantum efficiency spectra and (b) current-potential $(I-V)$ curves under polychromatic irradiation.

Table 3. Parameters Obtained from $I-V$ Curves for the Dye-Sensitized ZnO Solar Cells under Polychromatic Irradiation

$\begin{array}{ccccccc}\text { dye } & \begin{array}{c}V_{\text {oc }} \\ (\mathrm{V})\end{array} & \begin{array}{c}I_{\mathrm{sc}} \\ \left(\mathrm{mA} / \mathrm{cm}^{2}\right)\end{array} & \begin{array}{c}P_{\text {theo }}{ }^{a} \\ \left(\mathrm{~mW} / \mathrm{cm}^{2}\right)\end{array} & \begin{array}{c}P_{\max }{ }^{b} \\ \left(\mathrm{~mW} / \mathrm{cm}^{2}\right)\end{array} & \mathrm{ff}^{c} & \eta(\%)^{d} \\ (1) & 0.26 & 0.14 & 3.7 & 2.1 & 0.58 & 0.016 \\ (2) & 0.22 & 0.15 & 3.4 & 2.2 & 0.64 & 0.018 \\ (3) & 0.38 & 0.17 & 6.6 & 3.9 & 0.59 & 0.030\end{array}$

${ }^{a} P_{\text {theo }}=V_{\text {oc }} \times I_{\mathrm{sc}} \cdot{ }^{b} P_{\max }=I_{\max } \times V_{\max } \cdot{ }^{c} \mathrm{ff}=\left(P_{\max } / P_{\text {theo }}\right) .{ }^{d} \eta=$ overall efficiency.

asymmetry induces absorption over all visible wavelengths and emission with appreciable quantum yields in the NIR region. The observed changes in redox potentials, MLCT absorption and emission maxima, and excited state dynamics can be rationalized using Hammett $\sigma_{\mathrm{p}}$ parameters of $\mathrm{X}$, consistent with the important contribution of $-\mathrm{X}$ in modulating electron densities and orbital energies in these complexes, which can be used as dyes in DSCs over Zn NWs by anchoring the nitrile group of Mebpy-CN to the semiconductor surface. Enlarging the electron density asymmetry in these molecules by increasing the donor strength of $-\mathrm{X}$ gives more pronounced panchromatic shifting and higher photocurrent generation, a concept that may be useful for the development of more efficient DSCs.

\section{EXPERIMENTAL SECTION}

Materials and Instrumentation. All the chemicals used in this work were of analytical reagent grade and were used as purchased. $\mathrm{CH}_{3} \mathrm{CN}$ was freshly distilled over $\mathrm{KMnO}_{4}$. Infrared spectra $\left(4000-400 \mathrm{~cm}^{-1}\right)$ of the solids were obtained using 
KBr pellets with a Perkin-Elmer FTIR RX-I spectrometer. Characterization of the new complexes were carried out in $\mathrm{CH}_{3} \mathrm{CN}$ solutions by spectroscopic, electrochemical, and photophysical techniques. Construction and instruments used for characterizing the dye-sensitized $\mathrm{ZnO}$ nanowire-based solar cells are described below. NMR spectra were obtained in $\mathrm{CD}_{3} \mathrm{CN}$ with a Bruker $500 \mathrm{MHz}$ equipment operating at a frequency of $500.13 \mathrm{MHz}$ for ${ }^{1} \mathrm{H}$ NMR, $125.75 \mathrm{MHz}$ for ${ }^{13} \mathrm{C}$ $\mathrm{NMR}$, and $50.67 \mathrm{MHz}$ for ${ }^{15} \mathrm{~N}$ NMR. Electrospray ionization (ESI) mass spectra were recorded on a Bruker Esquire 6000 MS. Chemical analyses were carried out at INQUIMAE, University of Buenos Aires, Buenos Aires, Argentina, with an estimated error of $\pm 0.5 \%$. Electrochemical measurements were performed with BAS Epsilon EC equipment, using 0.1 M tetra$n$-butylammonium hexafluorophosphate (TBAH) as the supporting electrolyte in solutions that were thoroughly degassed with Ar prior to each measurement. A standard three-electrode arrangement was used with $\mathrm{Pt}$ as the working and auxiliary electrode and nonaqueous $\mathrm{Ag} / \mathrm{AgNO}_{3}(0.01 \mathrm{M}$ $\mathrm{AgNO}_{3}$ in $\mathrm{CH}_{3} \mathrm{CN}$ with $0.1 \mathrm{M}$ of $\mathrm{TBAH}$ ) as the reference electrode. For reversible electrochemical processes, reported $E_{1 / 2}$ values were calculated from cyclic voltammetry (CV) measurements as the averages between the peak values corresponding to the cathodic $\left(E_{\mathrm{c}}\right)$ and anodic $\left(E_{\mathrm{a}}\right)$ waves: $E_{1 / 2}=\left(E_{\mathrm{c}}+E_{\mathrm{a}}\right) / 2$. In cases where redox processes were quasireversible, potentials were obtained by differential pulse voltammetry (DPV). UV-vis absorption spectra were recorded on a Varian Cary 50 spectrophotometer using $1 \mathrm{~cm}$ quartz cells. Absorption spectra of solid films were measured in the same instrument using a solid sample holder for Cary 50/ 60. Raman spectra were obtained with a DXR spectrometer from Thermo Scientific equipped with a binocular Olympus microscope. Steady-state emission measurements were made at room temperature on a Shimadzu RF-5301 PC spectrofluorometer. Relative radiative quantum yields were calculated by eq 1

$$
\Phi_{\mathrm{x}}=\Phi_{\mathrm{r}}\left[\left(I_{\mathrm{x}} / A_{\mathrm{x}}\right) /\left(I_{\mathrm{r}} / A_{\mathrm{r}}\right)\right]\left(\eta_{\mathrm{x}} / \eta_{\mathrm{r}}\right)^{2}
$$

where $\Phi_{\mathrm{r}}$ is the quantum yield of a reference $\left(\left[\mathrm{Ru}(\mathrm{bpy})_{3}\right]\right.$ $\left(\mathrm{PF}_{6}\right)_{2}$ in acetonitrile $\left(\Phi_{\mathrm{r}}=0.095\right) .{ }^{35} \mathrm{UV}-$ vis spectroelectrochemical experiments were performed in $\mathrm{CH}_{3} \mathrm{CN}(0.1 \mathrm{M}$ TBAH) using a Honeycomb spectroelectrochemical cell (Pine Research) with $\mathrm{Pt}$ as the working and counter electrode and $\mathrm{Ag} / \mathrm{AgCl}$ as the reference electrode. Lifetime and transient spectra of the lowest-lying ${ }^{3} \mathrm{MLCT}$ excited states were obtained with the laser flash photolysis (LFP) setup described previously. ${ }^{36,37}$ Luminescence lifetimes were also determined by the time-correlated single photon counting (TCSPC) technique with a Tempro-01 apparatus from HORIBA Jobin Yvon (Glasgow, U.K.) using as the excitation pulse source an ultrafast $450( \pm 15) \mathrm{nm}$ Nanoled operating at $250 \mathrm{kHz}$. Fluorescence intensity decay was fitted with the fluorescence decay analysis software DAS6 of HORIBA Jobin Yvon by deconvolution of the pulse function using a single-exponential model function. All measurements were performed at room temperature in $\mathrm{CH}_{3} \mathrm{CN}$ solutions deoxygenated by bubbling high-purity $\operatorname{Ar}$ (>99.98, Indura SRL, Argentina) for $20 \mathrm{~min}$. Computational calculations were carried out with Gaussian 03. ${ }^{38}$ Molecular geometries were optimized using Becke's three-parameter hybrid functional ${ }^{39}$ with local terms of Lee, Yang, and Parr. ${ }^{40}$ For light atoms, a $6-311 \mathrm{G}(\mathrm{d}, \mathrm{p})$ basis set $^{41}$ was chosen, while for the ruthenium atom, LANL2DZ effective core potential with its corresponding basis set was used. ${ }^{42}$ The effect of the solvent $\left(\mathrm{CH}_{3} \mathrm{CN}\right)$ was included using the conductor-like polarizable continuum model (CPCM). ${ }^{43}$ Frequency calculations were performed to ensure that the optimized structure is a real minimum; no imaginary frequencies were found. No symmetry restrictions were imposed. From optimized structures, molecular orbital energies were determined and TD-DFT calculations were made. The contribution of the different groups of molecules to orbitals and electronic transitions were obtained using version 3.0 of the GaussSum software package. ${ }^{44}$

Syntheses. The precursors $\left[\mathrm{Ru}\left(4,4^{\prime}-\mathrm{X}_{2}-\mathrm{bpy}\right)_{2} \mathrm{Cl}_{2}\right]$ were prepared by following previously published methods. ${ }^{26,27}$ Mebpy-CN was prepared as reported previously. ${ }^{25} 4,4^{\prime}$ $\left(\mathrm{CH}_{3}\right)_{2}$-bpy and $4,4^{\prime}$ - $\left(\mathrm{OCH}_{3}\right)_{2}$-bpy were purchased from Sigma-Aldrich and 4,4' $-\left\{\mathrm{N}\left(\mathrm{CH}_{3}\right)_{2}\right\}_{2}$-bpy from Biosynth.

(i) $\left[\mathrm{Ru}\left(4,4^{\prime}-\left(\mathrm{CH}_{3}\right)_{2}-\mathrm{bpy}\right)_{2}(\mathrm{Mebpy}-\mathrm{CN})\right]\left(\mathrm{PF}_{6}\right)_{2}$ (1). A mixture of $26 \mathrm{mg}$ of Mebpy-CN $(0.13 \mathrm{mmol})$ and $72 \mathrm{mg}$ of $\left[\mathrm{Ru}\left(4,4^{\prime}\right.\right.$ $\left(\mathrm{CH}_{3}\right)_{2}$-bpy $\left.)_{2} \mathrm{Cl}_{2}\right](0.13 \mathrm{mmol})$ was added to $30 \mathrm{~mL}$ of deaerated methanol and heated at reflux under Ar for $4 \mathrm{~h}$. The obtained orange solution was rotaevaporated to dryness, dissolved in a minimum amount of water, and passed through a CM Sephadex C-25 column. The complex was eluted with 1 $\mathrm{M} \mathrm{HCl}$, and the collected fractions were rotaevaporated to dryness, dissolved in a minimum amount of water, and precipitated with a concentrated aqueous solution of $\mathrm{KPF}_{6}(1 \mathrm{~g}$ in $5 \mathrm{~mL}$ of water). The mixture was kept in the fridge overnight and filtered; the obtained orange powder was stored in vacuum over $\mathrm{P}_{4} \mathrm{O}_{10}$ for 1 day. Yield: $68 \mathrm{mg}$ (54\%). Chemical analyses and NMR were coherent with the formula $\left[\mathrm{Ru}\left(4,4^{\prime}\right.\right.$ $\left(\mathrm{CH}_{3}\right)_{2}$-bpy $\left.)_{2}(\mathrm{Mebpy}-\mathrm{CN})\right]\left(\mathrm{PF}_{6}\right)_{2} \cdot\left(\mathrm{KPF}_{6}\right)_{0.5}$. Anal. calcd (found) for $\mathrm{C}_{36} \mathrm{H}_{33} \mathrm{~N}_{7} \mathrm{P}_{2.5} \mathrm{~F}_{15} \mathrm{~K}_{0.5} \mathrm{Ru}: \mathrm{C}$, 41.3 (41.9); $\mathrm{H}$, 3.2(2.5); N, 9.4 (8.1). ${ }^{1} \mathrm{H}-\mathrm{NMR}$ (500.13 MHz, $\left.\mathrm{CD}_{3} \mathrm{CN}\right)$ 2.56 (s, 12H), 2.58(s, 3H), 7.26 (br, 4H), 7.33 (d, $6.1 \mathrm{MHz}$, $1 \mathrm{H}), 7.53$ (br, 4H), 7.59 (d, 6.1, 1H), 7.61 (d, $6.01 \mathrm{H}), 7.98$ (d, $6.0 \mathrm{~Hz}, 1 \mathrm{H}), 8.38(\mathrm{br}, 4 \mathrm{H}), 8.42(\mathrm{~s}, 1 \mathrm{H}), 8.76(\mathrm{~s}, 1 \mathrm{H}) .{ }^{13} \mathrm{C}-$ NMR (125.75 MHz, $\mathrm{CD}_{3} \mathrm{CN}$ ): 20.5, 20.1, 115.8, 124.9, 125.4, $125.8,128.2,128.3,129.1,150.4,150.7,150.9,152.3,152.9$, 155.3, 156.5, 158.9. ${ }^{15} \mathrm{~N}-\mathrm{NMR}\left(50.67 \mathrm{MHz}, \mathrm{CD}_{3} \mathrm{CN}\right): 241.7$, $242.8,269.0$. Positive ESI-MS ion clusters at $m / z: 809.8\{\mathrm{M}-$ $\left.\mathrm{PF}_{6}\right\}^{+}, 332.5\left\{\mathrm{M}-2 \mathrm{PF}_{6}\right\}^{2+}$.

(ii) $\left[\mathrm{Ru}\left(4,4^{\prime}-\left(\mathrm{OCH}_{3}\right)_{2}-\text { bpy }\right)_{2}(\mathrm{Mebpy}-\mathrm{CN})\right]\left(\mathrm{PF}_{6}\right)_{2}$ (2). A mixture of $20 \mathrm{mg}$ of Mebpy-CN $(0.10 \mathrm{mmol})$ and $60 \mathrm{mg}$ of $\left[\mathrm{Ru}\left(4,4^{\prime}\right.\right.$ $\left(\mathrm{OCH}_{3}\right)_{2}$-bpy $\left.)_{2} \mathrm{Cl}_{2}\right](0.10 \mathrm{mmol})$ was added to $30 \mathrm{~mL}$ of deaerated methanol and heated at reflux under Ar for $4 \mathrm{~h}$. The obtained reddish-orange solution was rotaevaporated to dryness, dissolved in a minimum amount of water, and passed through a CM Sephadex C-25 column. The complex was eluted with $1 \mathrm{M} \mathrm{HCl}$, and the collected fractions were rotaevaporated to dryness, dissolved in a minimum amount of water, and precipitated with a concentrated aqueous solution of $\mathrm{KPF}_{6}$ ( $1 \mathrm{~g}$ in $5 \mathrm{~mL}$ of water). The mixture was kept in the refrigerator overnight and filtered; the obtained dark orange powder was stored in vacuum over $\mathrm{P}_{4} \mathrm{O}_{10}$ for 1 day. Yield: 46 mg (45\%). Chemical analyses and NMR were coherent with the formula $\left[\mathrm{Ru}\left(4,4^{\prime}-\left(\mathrm{OCH}_{3}\right)_{2} \text {-bpy }\right)_{2}(\mathrm{Mebpy}-\mathrm{CN})\right]\left(\mathrm{PF}_{6}\right)_{2}$. $\left(\mathrm{KPF}_{6}\right)$. Anal. calcd (found) for $\mathrm{C}_{36} \mathrm{H}_{33} \mathrm{~N}_{7} \mathrm{O}_{4} \mathrm{P}_{3} \mathrm{~F}_{18} \mathrm{KRu}$ : C, 36.0 (35.9); H, 2.8(2.9); N, 8.2 (10.4). ${ }^{1} \mathrm{H}-\mathrm{NMR}$ (500.13 $\left.\mathrm{MHz}, \mathrm{CD}_{3} \mathrm{CN}\right) 2.58(\mathrm{~s}, 3 \mathrm{H}), 4.01(\mathrm{~s}, 12 \mathrm{H}), 6.93(\mathrm{br}, 2 \mathrm{H})$, 7.01 (br, 2H), 7.32 (br, 1H), 7.44 (br, 4H), 7.66 (d, $5.9 \mathrm{~Hz}$, $1 \mathrm{H}), 7.77(\mathrm{~d}, 5.9 \mathrm{~Hz}, 1 \mathrm{H}), 7.98(\mathrm{br}, 4 \mathrm{H}), 8.49(\mathrm{~s}, 1 \mathrm{H}), 8.76(\mathrm{~s}$, $1 \mathrm{H}) .{ }^{13} \mathrm{C}-\mathrm{NMR}\left(125.75 \mathrm{MHz}, \mathrm{CD}_{3} \mathrm{CN}\right): 20.1,56.7,111.0$, $113.7,121.2,125.5,128.6,149.8,150.8,152.2,152.5,158.1$, 159.0, 167.1, 167.3. ${ }^{15} \mathrm{~N}-\mathrm{NMR}\left(50.67 \mathrm{MHz}, \mathrm{CD}_{3} \mathrm{CN}\right): 225.2$, 
226.6, 244.1, 269.4. Positive ESI-MS ion clusters at $m / z: 873.9$ $\left\{\mathrm{M}-\mathrm{PF}_{6}\right\}^{+}$.

(iii) $\left[\mathrm{Ru}\left(4,4^{\prime}-\left\{\mathrm{N}\left(\mathrm{CH}_{3}\right)_{2}\right\}_{2}-\text {-bpy }\right)_{2}(\mathrm{Mebpy}-\mathrm{CN})\right]\left(\mathrm{PF}_{6}\right)_{2}$ (3). A mixture of $47 \mathrm{mg}$ of $\left[\mathrm{Ru}\left(4,4^{\prime}-\left\{\mathrm{N}\left(\mathrm{CH}_{3}\right)_{2}\right\}_{2} \text {-bpy }\right)_{2} \mathrm{Cl}_{2}\right] \mathrm{Cl}$ (0.067 mmol), $14 \mathrm{mg}$ of Mebpy-CN (0.071 mmol), and 0.2 $\mathrm{mL}$ of triethylamine was added to $10 \mathrm{~mL}$ of deaereated ethanol and heated to reflux under Ar for $4 \mathrm{~h}$. The obtained dark red solution was rotaevaporated to a minimum volume, recrystallized with ether, and filtered. The solid was dissolved in $5 \mathrm{~mL}$ of water and precipitated with a concentrated aqueous solution of $\mathrm{NH}_{4} \mathrm{PF}_{6}(1 \mathrm{~g}$ in $5 \mathrm{~mL}$ of water). The mixture was kept in a refrigerator overnight and filtered; the obtained dark red powder was stored in vacuum over $\mathrm{P}_{4} \mathrm{O}_{10}$ for 1 day. Yield: 26 $\mathrm{mg}(36 \%)$. Chemical analyses and NMR were coherent with the formula $\left[\mathrm{Ru}\left(4,4^{\prime}-\left\{\mathrm{N}\left(\mathrm{CH}_{3}\right)_{2}\right\}_{2} \text {-bpy }\right)_{2}\right.$ (Mebpy-CN)]$\left(\mathrm{PF}_{6}\right)_{2} \cdot \mathrm{H}_{2} \mathrm{O}$. Anal. calc (found) for $\mathrm{C}_{40} \mathrm{H}_{47} \mathrm{~N}_{11} \mathrm{OP}_{2} \mathrm{~F}_{12} \mathrm{Ru}$ : C, 44.1 (44.1); H, 4.3(4.2); N, 13.4 (14.1). ${ }^{1} \mathrm{H}-\mathrm{NMR}$ (500.13 $\left.\mathrm{MHz}, \mathrm{CD}_{3} \mathrm{CN}\right): 2.56(\mathrm{~s}, 3 \mathrm{H}), 3.13(\mathrm{~s}, 12 \mathrm{H}), 3.17(\mathrm{~s}, 12 \mathrm{H})$, 6.49 (br, 2H), 6.63 (br, 2H), 7.03 (br, 2H), 7.23 (br, 2H), 7.29 $(\mathrm{d}, 1 \mathrm{H}), 7.51(\mathrm{br}, 2 \mathrm{H}), 7.53(\mathrm{br}, 2 \mathrm{H}), 7.63(\mathrm{~d}, 1 \mathrm{H}), 7.76(\mathrm{~d}$, $1 \mathrm{H}), 8.10(\mathrm{~d}, 1 \mathrm{H}), 8.47(\mathrm{~s}, 1 \mathrm{H}), 8.71(\mathrm{~s}, 1 \mathrm{H}) .{ }^{13} \mathrm{C}-\mathrm{NMR}$ (125.75 MHz, $\left.\mathrm{CD}_{3} \mathrm{CN}\right): 20.1,39.1,105.8,109.3,121.1,124.0$, $124.9,128.0,148.2,148.9,149.5,150.6,152.3,154.2,156.6$, 157.0, 159.4. ${ }^{15} \mathrm{~N}-\mathrm{NMR}$ (50.67 MHz, $\left.\mathrm{CD}_{3} \mathrm{CN}\right): 68.0,204.1$, 205.9, 252.0, 272.2. Positive ESI-MS ion clusters at $m / z: 925.9$ $\left\{\mathrm{M}-\mathrm{PF}_{6}\right\}^{+}, 390.3\left\{\mathrm{M}-2 \mathrm{PF}_{6}\right\}^{2+}$.

FTO IZnO NWs. For $\mathrm{ZnO} \mathrm{NW}$ growth, glass-FTO substrates (Sigma-Aldrich) of $2 \times 1.5 \mathrm{~cm}$ were used. They were initially cleaned in ultrasonic baths of ethanol and acetone for $3 \mathrm{~min}$. Then, seeds of $\mathrm{ZnO}$ were made on glass/ FTO using a spin-coating deposit of an ethanolic solution of $20 \mathrm{mM}$ zinc acetate dihydrate (spinning at $1500 \mathrm{rpm}$ during 1 min) followed by drying at $125^{\circ} \mathrm{C}$ for $1 \mathrm{~min}$. This procedure was repeated 5 times, and finally the substrates were heated at $125{ }^{\circ} \mathrm{C}$ for $4 \mathrm{~h}$ to improve the seed adherence. In a second step, $\mathrm{ZnO}$ NWs were synthesized by a solvothermal method: $\mathrm{ZnO}$-seeded substrates were put in $25 \mathrm{~mL}$ polytetrafluoroethylene (PTFE) vessels, which were then filled with a solution of distilled water (DW), hexamethylenetetramine (HMTA), and zinc nitrate dihydrate $(0.5 \mathrm{M}$, aqueous solutions). The vessels were placed inside a stainless steel autoclave and heated at $125{ }^{\circ} \mathrm{C}$ for $4 \mathrm{~h}$. The autoclaves were then cooled down to room temperature, and after an hour, each sample was taken out of the vessel, rinsed with DW, and dried in air.

Characterization of the FTOIZnO NWs was carried out using a Zeiss Supra 55VP scanning electron microscope (SEM). X-ray powder diffraction analyses between 30 and $40^{\circ}$ were carried out in an X-ray diffraction (XRD) RIGAKU Mini Flex 600 instrument using $\mathrm{Cu} \mathrm{K} \alpha_{1}$ radiation. UV-visible, and Raman measurements of films were made in the equipment already described.

Ru Complexes/ZnO Solar Cells. In order to assemble the DSCs, the FTO/ZnO NW samples were heated at $100{ }^{\circ} \mathrm{C}$ for $60 \mathrm{~min}$ to remove traces of water and then immersed in solutions of complexes $1-3$ in $\mathrm{CH}_{3} \mathrm{CN}(\mathrm{C}=1.2 \mathrm{mM})$ for $24 \mathrm{~h}$. Samples were rinsed with DW and dried in air to obtain the different sensitized electrodes. They were characterized by Raman and UV-vis absorption techniques.

Solar cells were subsequently assembled with an area of 1 $\mathrm{cm}^{2}$ as described in Figure S1: a glass-FTO with a layer of Pt (deposited by sputtering) was used as a counter electrode, and a solution $0.5 \mathrm{M} \mathrm{KI} / 0.005 \mathrm{M} \mathrm{I}_{2}$ in acetonitrile was used as the electrolyte. Acetonitrile was chosen as the solvent since most data for DSCs are reported in this media, ${ }^{3}$ and no experimental evidence of adsorption of this solvent on the $\mathrm{ZnO}$ surface has been obtained. Double-sided tape (thickness of $60 \mu \mathrm{m}$ ) was used as an electrode separator. Solar cells were characterized using $I-V$ (current-potential) curves and quantum efficiency (QE) measurements as described previously. ${ }^{33}$

The performance of each DSC for solar energy conversion was evaluated using the quantum efficiency/incident photon to charge carrier efficiency (QE/IPCE) Newport measurement kit, consisting of a $300 \mathrm{~W}$ ozone-free Xe lamp, chopper, monochromator, detector, and other accessories. The cells were irradiated using a "homemade" solar simulator, which was assembled with a metallic vapor lamp (Metalarc Sylvania HISYHX $400 \mathrm{~W}$ ). Considering the distance from the lamp and solar cell $(15 \mathrm{~cm})$, the polychromatic irradiance was estimated to be $130 \pm 5 \mathrm{~mW} \mathrm{~cm}^{-2}$.

\section{ASSOCIATED CONTENT}

\section{Supporting Information}

The Supporting Information is available free of charge at https://pubs.acs.org/doi/10.1021/acsomega.0c00243.

Construction of DSCs, FTIR spectrum of complex 3, 1D and 2D NMR spectra and assignments of complex 3, UV-vis absorption data of complexes 1-3, CV and DPV curves of complex 3, emission spectra of complexes 1-3, TD-DFT calculations and assignments of complexes $\mathbf{1 - 3}$ and $\mathbf{3}^{+}$, EDAX of $\mathrm{ZnO}$ NWs, UV-vis absorption spectra of bare and sensitized FTO $\mathrm{InO}$ NWs, and Raman spectra of sensitized FTO IZnO NWs (PDF).

\section{AUTHOR INFORMATION}

\section{Corresponding Author}

Néstor E. Katz - INQUINOA (UNT- CONICET), Instituto de Quimica Fisica, Facultad de Bioquimica, Quimica y Farmacia, Universidad Nacional de Tucumán, T4000INI San Miguel de Tucumán, Argentina; 이이이.org/0000-0001-5576-2692; Phone: (+54)(381)(4200960); Email: nkatz@ fbqf.unt.edu.ar; Fax: $(+54)(381)(4248169)$

\section{Authors}

Fernando F. Salomón - INQUINOA (UNT- CONICET), Instituto de Quimica Fisica, Facultad de Bioquimica, Quimica y Farmacia, Universidad Nacional de Tucumán, T4000INI San Miguel de Tucumán, Argentina

Nadia C. Vega - INQUINOA (UNT-CONICET), Instituto de Quimica Fisica, Facultad de Bioquimica, Quimica y Farmacia, Universidad Nacional de Tucumán, T4000INI San Miguel de Tucumán, Argentina

Teodor Parella - Servei de RMN, Universitat Autonóma de Barcelona, Bellaterra E-08193, Spain; ㅇo orcid.org/00000002-1914-2709

Faustino Eduardo Morán Vieyra - INBIONATEC (UNSECONICET), Universidad Nacional de Santiago del Estero, 4206 Santiago del Estero, Argentina

Claudio D. Borsarelli - INBIONATEC (UNSE-CONICET), Universidad Nacional de Santiago del Estero, 4206 Santiago del Estero, Argentina

Claudia Longo - Institute of Chemistry, University of Campinas, UNICAMP, 13083-970 Campinas, Sao Paulo, Brazil

Mauricio Cattaneo - INQUINOA (UNT- CONICET), Instituto de Quimica Fisica, Facultad de Bioquimica, Quimica y 
Farmacia, Universidad Nacional de Tucumán, T4000INI San Miguel de Tucumán, Argentina

Complete contact information is available at: https://pubs.acs.org/10.1021/acsomega.0c00243

\section{Notes}

The authors declare no competing financial interest.

\section{ACKNOWLEDGMENTS}

We thank CONICET (Grant PIP-2015-098), FONCyT (Grant PICT-2016-0553), and UNT (Grant PIUNT 26D/ 620) for financial support. F.F.S. and N.C.V. thank CONICET for fellowships. M.C., F.E.M.V., C.D.B., and N.E.K. are members of the Research Career (CONICET). T.P. acknowledges financial support for this research provided by Spanish MINECO (Project PGC2018-095808-B-I00). We thank Dr. Miriam Pérez (UAB) for MS measurements, Dr. Mónica Tirado (FACET, UNT) for letting us use their facilities, and Dr. Carolina Navarro (FQByF, UNT) for XRD measurements. We also thank Bioq. Luciano Martinez and Ing. Hernán Esquivel (CIME-CONICET-UNT) for SEM and EDS measurements.

\section{REFERENCES}

(1) Grätzel, M. Dye-Sensitized Solar Cells. J. Photochem. Photobiol. C 2003, 4, 145-153.

(2) Juris, A.; Balzani, V.; Barigelletti, F.; Campagna, S.; Belser, P.; von Zelewsky, A. Ru(II) Polypyridine Complexes: Photophysics, Photochemistry, Eletrochemistry, and Chemiluminescence. Coord. Chem. Rev. 1988, 84, 85-277.

(3) Hagfeldt, A.; Boschloo, G.; Sun, L.; Kloo, L.; Pettersson, H. DyeSensitized Solar Cells. Chem. Rev. 2010, 110, 6595-6663.

(4) Sharma, K.; Sharma, V.; Sharma, S. S. Dye-Sensitized Solar Cells : Fundamentals and Current Status. Nanoscale Res. Lett. 2018, 13, 381.

(5) Nazeeruddin, M. K.; Humphry-Baker, R.; Liska, P.; Grätzel, M. Investigation of Sensitizer Adsorption and the Influence of Protons on Current and Voltage of a Dye-Sensitized Nanocrystalline $\mathrm{TiO}_{2}$ Solar Cell. J. Phys. Chem. B 2003, 107, 8981-8987.

(6) Nazeeruddin, M. K.; Péchy, P.; Renouard, T.; Zakeeruddin, S. M.; Humphry-Baker, R.; Comte, P.; Liska, P.; Cevey, L.; Costa, E.; Shklover, V.; Spiccia, L.; Deacon, G. B.; Bignozzi, C. A.; Grätzel, M. Engineering of Efficient Panchromatic Sensitizers for Nanocrystalline $\mathrm{TiO}_{2}$-Based Solar Cells. J. Am. Chem. Soc. 2001, 123, 1613-1624.

(7) Bessho, T.; Yoneda, E.; Yum, J.-H.; Guglielmi, M.; Tavernelli, I.; Imai, H.; Rothlisberger, U.; Nazeeruddin, M. K.; Grätzel, M. New Paradigm in Molecular Engineering of Sensitizers for Solar Cell Applications. J. Am. Chem. Soc. 2009, 131, 5930-5934.

(8) Pal, A. K.; Nag, S.; Ferreira, J. G.; Brochery, V.; La Ganga, G.; Santoro, A.; Serroni, S.; Campagna, S.; Hanan, G. S. Red-Emitting $\left[\mathrm{Ru}(\mathrm{bpy})_{2}(\mathrm{~N}-\mathrm{N})\right]^{2+}$ Photosensitizers:Emission from a Ruthenium(II) to $2,2^{\prime}$-Bipyridine ${ }^{3}$ MLCT State in the Presence of Neutral Ancillary “Super Donor" Ligands. Inorg. Chem. 2014, 53, 1679-1689.

(9) O’Regan, B.; Grätzel, M. A Low-Cost, High-Efficiency Solar Cell Based on Dye-Sensitized Colloidal $\mathrm{TiO}_{2}$ Films. Nature 1991, 353, 737-740.

(10) Grätzel, M. Photoelectrochemical Cells. Nature 2001, 414, 338-344.

(11) Özgür, Ü.; Hofstetter, D.; Morkoç, H. ZnO Devices and Applications : A Review of Current Status and Future Prospects. Proc. IEEE 2010, 98, 1255-1268.

(12) Rodnyi, P. A.; Khodyuk, I. V. Optical and Luminescence Properties of Zinc Oxide ( Review ). Opt. Spectrosc. 2011, 111, 776785.

(13) Lee, J.-H.; Ko, K.-H.; Park, B.-O. Electrical and Optical Properties of $\mathrm{ZnO}$ Transparent Conducting Films by the Sol - Gel Method. J. Cryst. Growth 2003, 247, 119-125.
(14) Wisz, G.; Virt, I.; Sagan, P.; Potera, P.; Yavorskyi, R. Structural, Optical and Electrical Properties of Zinc Oxide Layers Produced by Pulsed Laser Deposition Method. Nanoscale Res. Lett. 2017, 12, 253.

(15) He, J. H.; Hsin, C. L.; Liu, J.; Chen, L. J.; Wang, Z. L. Piezoelectric Gated Diode of a Single ZnO Nanowire. Adv. Mater. 2007, 19, 781-784.

(16) Emanetoglu, N. W.; Gorla, C.; Liu, Y.; Liang, S.; Lu, Y. Epitaxial ZnO Piezoelectric Thin Films for Saw Filters. Mater. Sci. Semicond. Process. 1999, 2, 247-252.

(17) Vega, N. C.; Wallar, R.; Caram, J.; Grinblat, G.; Tirado, M.; LaPierre, R. R.; Comedi, D. ZnO Nanowire Co-Growth on $\mathrm{SiO}_{2}$ and $\mathrm{C}$ by Carbothermal Reduction and Vapour Advection. Nanotechnology 2012, 23, 275602.

(18) Grinblat, G.; Capeluto, M. G.; Tirado, M.; Bragas, A. V.; Comedi, D. Hierarchical ZnO Nanostructures : Growth Mechanisms and Surface Correlated Photoluminescence. Appl. Phys. Lett. 2012, 100, 233116.

(19) Vega, N. C.; Tirado, M.; Comedi, D.; Rodriguez, A.; Rodriguez, T.; Hughes, G. M.; Grovenor, C. R. M.; Audebert, F. Electrical, Photoelectrical and Morphological Properties of $\mathrm{ZnO}$ Nanofiber Networks Grown on $\mathrm{SiO}_{2}$ and on Si Nanowires. Mater. Res. 2013, 16, 597-602.

(20) Vega, N. C.; Marin, O.; Tosi, E.; Grinblat, G.; Mosquera, E.; Moreno, M. S.; Tirado, M.; Comedi, D. The Shell Effect on the Room-Temperature Photoluminescence from $\mathrm{ZnO} / \mathrm{MgO}$ Core/Shell Nanowires: Exciton-Phonon Coupling and Strain. Nanotechnology 2017, 28, 275702.

(21) Grinblat, G.; Bern, F.; Barzola-quiquia, J.; Tirado, M.; Comedi, D.; Esquinazi, P. Luminescence and Electrical Properties of Single $\mathrm{ZnO} / \mathrm{MgO}$ Core/Shell Nanowires. Appl. Phys. Lett. 2014, 104, 103113.

(22) Anta, J. A.; Guillén, E.; Tena-Zaera, R. ZnO-Based DyeSensitized Solar Cells. J. Phys. Chem. C 2012, 116, 11413-11425.

(23) Zhang, Q.; Dandeneau, C. S.; Zhou, X.; Cao, G. ZnO Nanostructures for Dye-Sensitized Solar Cells. Adv. Mater. 2009, 21, 4087-4108.

(24) Vega, N. C.; Mecchia Ortiz, J. H.; Tirado, M.; Katz, N. E.; Comedi, D. $\mathrm{ZnO}$ Nanowire Sensitization with $\mathrm{Ru}$ Polypyridyl Complexes : Charge-Transfer Probed by Spectral and Relaxation Photocurrent Measurements. Mater. Res. Express 2018, 5, No. 075020.

(25) Mecchia Ortiz, J. H.; Vega, N.; Comedi, D.; Tirado, M.; Romero, I.; Fontrodona, X.; Parella, T.; Morán Vieyra, F. E.; Borsarelli, C. D.; Katz, N. E. Improving the Photosensitizing Properties of Ruthenium Polypyridyl Complexes Using 4-Methyl2,2'-bipyridine-4'-carbonitrile as an Auxiliary Ligand. Inorg. Chem. 2013, 52, 4950-4962.

(26) Sullivan, B. P.; Salmon, D. J.; Meyer, T. J. Mixed Phosphine 2,2'-Bipyridine Complexes of Ruthenium. Inorg. Chem. 2002, 17, 3334-3341.

(27) Pannwitz, A.; Prescimone, A.; Wenger, O. S. Ruthenium(II)Pyridylimidazole Complexes as Photoreductants and PCET Reagents. Eur. J. Inorg. Chem. 2017, 609-615.

(28) Hansch, C.; Leo, A.; Taft, R. W. A Survey of Hammett Substituent Constants and Resonance and Field Parameters. Chem. Rev. 1991, 91, 165-195.

(29) Maestri, M.; Armaroli, N.; Balzani, V.; Constable, E. C.; Cargill Thompson, A. M. W. Complexes of the Ruthenium(II)-2,2':6',2"terpyridine Family. Effect of Electron-Accepting and -Donating Substituents on the Photophysical and Electrochemical Properties. Inorg. Chem. 1995, 34, 2759-2767.

(30) Dodsworth, E. S.; Lever, A. B. P. Correlation of Electronic Charge Transfer Transitions and Electrochemical Potentials. The Bispyrazine(tetracarbonyl)molybdenum(0) System in Various Solvents. Chem. Phys Lett. 1984, 112, 567-570.

(31) Wallin, S.; Davidsson, J.; Modin, J.; Hammarström, L. Femtosecond Transient Absorption Anisotropy Study on $[\mathrm{Ru}-$ $\left.(\text { bpy })_{3}\right]^{2+}$ and $\left[\mathrm{Ru}(\text { bpy })(\text { py })_{4}\right]^{2+}$. Ultrafast Interligand Randomization of the MLCT State. J. Phys Chem. A 2005, 109, 4697-4704. 
(32) Caspar, J. V.; Kober, E. M.; Sullivan, B. P.; Meyer, T. J. Application of the Energy Gap Law to the Decay of Charge-transfer Excited States. J. Am. Chem. Soc. 1982, 104, 630-632.

(33) Mecchia Ortiz, J. H.; Longo, C.; Katz, N. E. Polypyridyl Ruthenium Complexes Containing Anchoring Nitrile Groups as $\mathrm{TiO}_{2}$ Sensitizers for Application in Solar Cells. Inorg. Chem. 2015, 55, 6972.

(34) Keis, K.; Lindgren, J.; Lindquist, S.-E.; Hagfeldt, A. Studies of the Adsorption Process of $\mathrm{Ru}$ Complexes in Nanoporous $\mathrm{ZnO}$ Electrodes. Langmuir 2000, 16, 4688-4694.

(35) Ishida, H.; Tobita, S.; Hasegawa, Y.; Katoh, R.; Nozaki, K. Recent Advances in Instrumentation for Absolute Emission Quantum Yield Measurements. Coord. Chem. Rev. 2010, 254, 2449-2458.

(36) Cattaneo, M.; Fagalde, F.; Katz, N. E.; Borsarelli, C. D.; Parella, T. pH-Induced Luminescence Changes of Chromophore-Quencher Tricarbonylpolypyridylrhenium(I) Complexes with 4-Pyridinealdazine. Eur. J. Inorg. Chem. 2007, 3, 5323-5332.

(37) Cattaneo, M.; Fagalde, F.; Borsarelli, C. D.; Katz, N. E. Improvement of the Dynamic Range of $\mathrm{pH}$ Sensing by Using a Luminescent Tricarbonylpolypyridylrhenium(I) Complex with Three Different Protonation Sites. Inorg. Chem. 2009, 48, 3012-3017.

(38) Frisch, M. J.; Trucks, G. W.; Schlegel, H. B.; Scuseria, G. E.; Robb, M. A.; Cheeseman, J. R.; Montgomery, Jr., J. A.; Vreven, T.; Kudin, K. N.; Burant, J. C.; Millam, J. M.; Iyengar, S. S.; Tomasi, J.; Barone, V.; Mennucci, B.; Cossi, M.; Scalmani, G.; Rega, N.; Petersson, G. A.; Nakatsuji, H.; Hada, M.; Ehara, M.; Toyota, K.; Fukuda, R.; Hasegawa, J.; Ishida, M.; Nakajima, T.; Honda, Y.; Kitao, O.; Nakai, H.; Klene, M.; Li, X.; Knox, J. E.; Hratchian, H. P.; Cross, J. B.; Bakken, V; Adamo, C.; Jaramillo, J.; Gomperts, R.; Stratmann, R. E.; Yazyev, O.; Austin, A. J.; Cammi, R.; Pomelli, C.; Ochterski, J. W.; Ayala, P. Y.; Morokuma, K.; Voth, G. A.; Salvador, P.; Dannenberg, J. J.; Zakrzewski, V. G.; Dapprich, S.; Daniels, A. D.; Strain, M. C.; Farkas, O.; Malick, D. K.; Rabuck, A. D.; Raghavachari, K.; Foresman, J. B.; Ortiz, J. V.; Cui, Q.; Baboul, A. G.; Clifford, S.; Cioslowski, J.; Stefanov, B. B.; Liu, G.; Liashenko, A.; Piskorz, P.; Komaromi, I.; Martin, R. L.; Fox, D. J.; Keith, T.; Al-Laham, M. A.; Peng, C. Y.; Nanayakkara, A.; Challacombe, M.; Gill, P. M. W.; Johnson, B.; Chen, W.; Wong, M. W.; Gonzalez, C.; Pople, J. A. Gaussian 03, Revision C.02. Gaussian, Inc.: Wallingford, CT, 2004.

(39) Becke, A. D. Density-Functional Thermochemistry. III. The Role of Exact Exchange. J. Chem. Phys. 1993, 98, 5648-5652.

(40) Lee, C.; Yang, W.; Parr, R. G. Development of the ColleSalvetti Correlation-Energy Formula into a Functional of the Electron Density. Phys. Rev. B 1988, 37, 785-789.

(41) Krishnan, R.; Binkley, J. S.; Seeger, R.; Pople, J. A. SelfConsistent Molecular Orbital Methods. XX. A Basis Set for Correlated Wave Functions. J. Chem. Phys. 1980, 72, 650-654.

(42) Hay, P. J.; Wadt, W. R. Ab Initio Effective Core Potentials for Molecular Calculations. Potentials for the Transition Metal Atoms Sc to Hg. J. Chem. Phys. 1985, 82, 270-283.

(43) Barone, V.; Cossi, M. Quantum Calculation of Molecular Energies and Energy Gradients in Solution by a Conductor Solvent Model. J. Phys. Chem. A 1998, 102, 1995-2001.

(44) O’Boyle, N. M.; Tenderholt, A. L.; Langner, K. M. Cclib: A Library for Package-Independent Computational Chemistry Algorithms. J. Comput. Chem. 2008, 29, 839-845. 